流 れ

\title{
新たなコンセプトを探し求めて
}

磯 達也 ${ }^{1}$

1 群馬県前橋市昭和町3-39-22 群馬大学大学院医学系研究科教育研究支援センター医療開発医科学部門

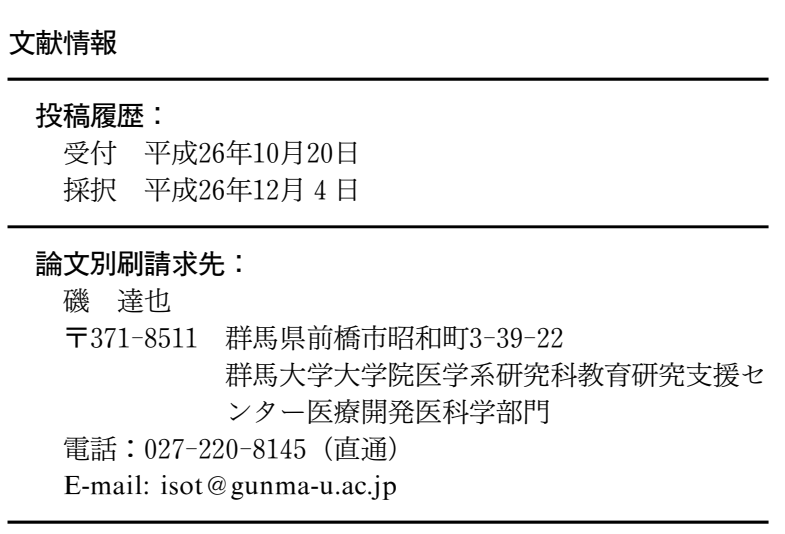

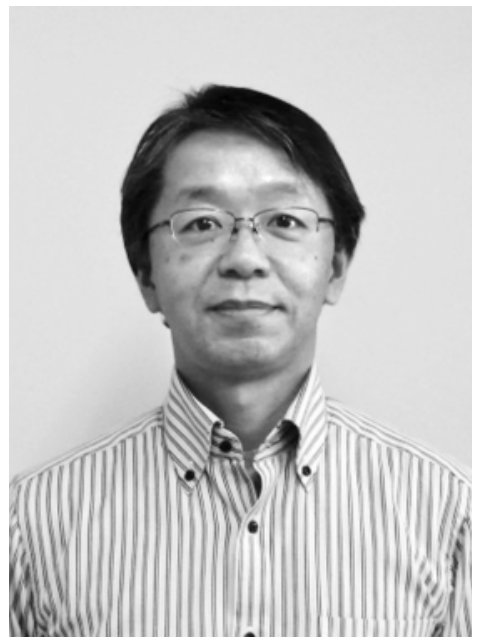

この度,「流れ」の紙面の中でこれまでの研究経緯を紹介 する機会を頂きましたので, 循環器内科医である私が, ど のようなスタイルでどのような研究をしてきたのか，お話 ししたいと思います。

昨今, 新規分子を探索するために, 様々なスクリーニン グ法が使われます. 私は, これまでに二回, 新規性の高い分 子と遭遇することが出来ました．スクリーニング自体は運 に左右される部分が大きいものですが，スクリーニング後 の展開は研究者の力量にかかってきます. 膨大な情報処理 の後, 複数の候補分子からターゲットを選定し, その分子 にどのような新規性・概念を打ち出せるか, 手探りの状態 から始まります．私自身がスクリーニングから始めた二つ のプロジェクトの概要をご紹介いたします．

\section{Notch シグナルと心血管病}

米国・南カリファルニア大学留学中に, Notch シグナルの 標的転写因子 HERP1 (Hey2) と HERP2 (Hey1) を単離・ 同定し, 遺伝子制御のメカニズムについて研究・発表して まいりました. ${ }^{1,2}$ 当時は心血管系における Notch シグナル の役割がほとんど解明されておらず, 新規フィールドへの 挑戦でした. 現在では Notch シグナルが心血管の発生過程 に必須のシグナルであることが次々と発表され，すそ野の 大きな広がりをみせております. Notch フィールドの拡大 のおかげで, 当時の研究から派生した私の review paper は,
今でも多くの研究者から引用されています (J Cell Physiol 200333 citation 844, ATVB 20034; citation 288, 2014 年 10 月 時点). 㷌国後も心血管系におけるNotch シグナルの役割 の解析に取り組んで, これまでに, Notch シグナルが平滑筋 の分化を促進すること, ${ }^{5}$ Notch シグナルの標的因子の HERP1 が平滑筋分化を抑制すること, ${ }^{6}$ Notch リガンド D114 が動脈分化を促進すること7などを報告してきました.

\section{筋型毛細血管内皮細胞を介すると脂肪酸代謝の 制御機構と全身代謝への影響}

最近では，毛細血管内皮細胞の機能解析に研究が大きく シフトしています.これも, Notch シグナル標的因子のスク リーニングから始まったものです，脂肪酸結合蛋白 FABP4・FABP5 は細胞内での脂肪酸の貯蔵と輸送に関与 します. FABP4 は主に脂肪細胞に, FAPB5 は主に皮膚の 扁平上皮細胞に高発現することが知られていましたが，こ れら FABP4/5 が毛細血管内皮細胞にも高発現することが わかりました. FABP4/5 ダブルノックアウト (DKO) マウ スでは, 高脂肪食負荷による一連のメタボリックシンド ローム様症候 (肥満, インスリン抵抗性, 糖尿病) が著しく 減弱することが知られていましたが, これらの表現型の主 な成因が, 毛細血管内皮細胞に発現するFABP4/5 の欠損 によることが明らかになりました.つまり, 受動的拡散で はない毛細血管内皮細胞の FABP4/5 を介する輸送により 
脂肪酸は血中から心筋・骨格筋の間質へ効率よく運搬され ること(経内皮的脂肪酸輸送)，その欠失により DKO マウ スの心臓・骨格筋では脂肪酸取り込みが減少すること, そ して，エネルギー基質不足を補うために代償的にグルコー ス代謝が著しく京進することがわかったのです。この心 筋・骨格筋でのグルコース代謝穴進が DKO マウスの代謝 改善の表現型の主因だったわけです.8

絶食時には通常, 多くの臓器でエネルギー基質の依存度 が脂肪酸へシフトします.そこで, 心臓・骨格筋の脂肪酸利 用能が低下寸るDKO マウスにおいて，長期絶食下での全 身エネルギー代謝がどのように変化するか検討しました， DKO マウスでは, 絶食に伴い低血糖・高遊離脂肪酸血症・ 高ケトン体血症・著明な脂肪肝が認められました. ${ }^{9} さ ら に ，$ 絶食後に寒冷環境下 $\left(4^{\circ} \mathrm{C}\right)$ に暴露すると, DKO マウスは急 速な低体温を呈しました. ${ }^{10}$ 以上より, DKO マウスは, 絶食 時に最も重要な脂肪酸が利用できないため，長期の飢餓や 低温など, 想定されうる過酷な自然環境に対して非耐性の マウスであることが明らかとなりました。

新規性の高い分野の研究は, 実験系の確立や概念の構築 に苦難を伴います。しかしながら，それらが現実化されて いく過程の中で数多くの「ときめき」を感じ, 論文が掲載さ れれば大きな反響があり，素直に喜びを感じます，そのよ うな苦しくも楽しい研究生活が送れる現在の研究環境に感 謝し, 今後も新しい概念を積み重ねていきたいと思ってい ます．また，一緒にはたらくスタッフには，研究に「ときめ き」を感じていただければと思います。
文献

1. Iso $\mathrm{T}$, et al. Herp, a new primary target of notch regulated by ligand binding. Mol Cell Biol 2001; 21: 6071-6079.

2. Iso $\mathrm{T}$, et al. Herp, a novel heterodimer partner of hes/e(spl) in notch signaling. Mol Cell Biol 2001; 21: 6080-6089.

3. Iso T, et al. Hes and herp families: Multiple effectors of the notch signaling pathway. J Cell Physiol 2003; 194: 237-255.

4. Iso $\mathrm{T}$, et al. Notch signaling in vascular development. Arterioscler Thromb Vasc Biol 2003; 23: 543-553.

5. Doi $\mathrm{H}$, Iso $\mathrm{T}$, et al. Jaggedl-selective notch signaling induces smooth muscle differentiation via a rbp-jkappadependent pathway. J Biol Chem 2006; 281: 28555-28564.

6. Doi $\mathrm{H}$, Iso $\mathrm{T}$, et al. Herp1 inhibits myocardin-induced vascular smooth muscle cell differentiation by interfering with srf binding to carg box. Arterioscler Thromb Vasc Biol 2005; 25: 2328-2334.

7. Iso $\mathrm{T}$, et al. Dll4-selective notch signaling induces ephrinb2 gene expression in endothelial cells. Biochem Biophys Res Commun 2006; 341: 708-714.

8. Iso $\mathrm{T}$, et al. Capillary endothelial fatty acid binding proteins 4 and 5 play a critical role in fatty acid uptake in heart and skeletal muscle. Arterioscler Thromb Vasc Biol 2013; 33: 2549-2557.

9. Syamsunarno MR, Iso $T$, et al. A critical role of fatty acid binding protein 4 and 5 (fabp4/5) in the systemic response to fasting. PloS One 2013; 8: e79386.

10. Syamsunarno MR, Iso T, et al. Fatty acid binding protein 4 and 5 play a crucial role in thermogenesis under the conditions of fasting and cold stress. PloS One 2014; 9: e90825. 